\title{
Hand injuries in farmers: A 10-year review
}

\author{
Duncan AG Miles MD FRCSC, MM Bendago MBBCh FRCSC, JA Beveridge MD FRCSC, \\ PS Chang MD CCFP FRCSC, CH Lee MB FRCSC \\ Division of Plastic Surgery, Pasqua Hospital, Regina, Saskatchewan
}

\section{DAG Miles, MM Bendago, JA Beveridge, PS Chang, CH Lee. Hand injuries in farmers: A 10-year review. Can J Plast Surg 2001;9(4):147-153.}

\begin{abstract}
A retrospective review of hand injuries in farmers was carried out in the Regina Health District. One hundred twelve injuries requiring hospitalization were recorded over 10 years. Injuries presented throughout the year, with a peak in August that was associated with the harvest. An increased rate of injury was also associated with age. Entanglement in machinery comprised $84 \%$ of injuries, of which swathers, power take-offs, combines and augers made up the majority of causes. Eighty-one per cent of injuries were open, with injury to the index, long and ring fingers being most common. The overall amputation rate was $30 \%$. Patterns of injury relating to each machine were collected, and from these results a classification system is proposed.
\end{abstract}

Key Words: Farming; Hand injury

\section{Blessures aux mains en milieu agricole : étude rétrospective sur dix ans}

RÉSUMÉ : Une étude rétrospective sur les blessures aux mains en milieu agricole a été menée dans le district de santé de Regina. Cent douze (112) blessures ayant nécessité une hospitalisation ont été relevées sur une période de dix ans. Les blessures sont survenues tout au long de l'année, mais surtout en août au moment des récoltes. L'âge a aussi été associé à un taux élevé de blessures. L'entraînement par un mécanisme de machinerie (faucheuse-andaineuse, prise de force, moissonneuse-batteuse, vis sans fin) a été à l'origine de $84 \%$ des blessures. Dans $81 \%$ des cas, il y a eu blessure ouverte aux doigts; l'index, le majeur et l'annulaire ont été les plus touchés. Le taux global d'amputation a été de $30 \%$. Nous avons recueilli des données sur les types de blessures associés aux différentes machines et nous proposons, à partir des résultats obtenus, un système de classification.

$\mathrm{F}$ arming is a hazardous occupation. The fatality rate for farmers is 2.5 times higher than the mean for all other industries in Canada $(1,2)$. Upper extremity injuries are the most common nonfatal injuries in farmers (2). Hand surgeons who deal with these injuries note patterns in their presentation and scope of injury.

Regina is the tertiary referral centre for southeastern Saskatchewan. It services most of rural Saskatchewan and sees many primary and tertiary problems. It is hypothesized that a retrospective review of hand injuries in farmers would reveal patterns in time, scope and mechanism of injury.

\section{MATERIALS AND METHODS}

A retrospective chart review from 1989 to 1999 was carried out at the Regina General Hospital and the Pasqua Hospital.
International Classification of Diseases, 9th revision (ICD-9) codes E849.1 and E919.0 relating to injury on the farm were used to pull the records. Charts were then manually sorted relating to upper extremity injury. Only hospitalized patients were included.

Data retrieved from the charts were name, age, sex, date of injury, place of injury, body part injured, structures injured, mechanism of injury, associated injuries and treatment.

\section{RESULTS}

Referrals were from southeastern Saskatchewan (Figure 1). One hundred twelve injuries were noted in the 111 patients. There was one fatality (Table 1). One hundred two patients were men with a mean age of 44 years (range two to 74 years) (Table 1). August was the most common month for injury 


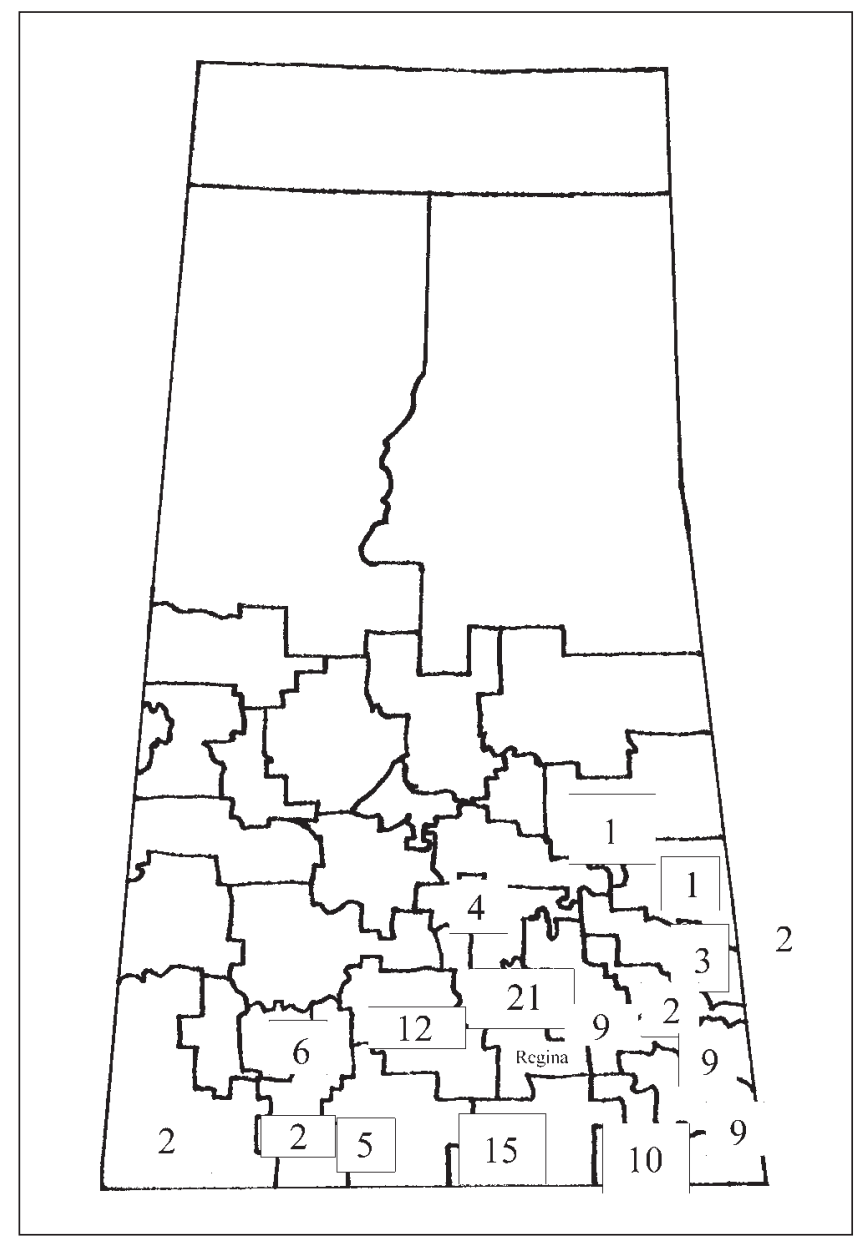

Figure 1) Referral by Health Districts

(Table 2). The body part injured was classified by the digits, metacarpal, carpus and forearm. The index, long and ring fingers were the most commonly injured (Table 3 ).

Ninety-four of 112 injuries involved entanglement in machinery (Table 4). Fifty-five of 94 injuries involved four machines: swather (eight of 55), power take-off (PTO) (12 of $55)$, combine (15 of 55) and auger (20 of 55) (Table 5). Ninety-one injuries were associated with open wounds (Tables 6,7). Eighty-seven injuries were associated with a bony injury (Table 7). Thirty-three amputations were performed (Table 8). Eight upper extremity injuries were associated with other injuries, four of which were related to PTO injuries (Tables 9,10).

Twenty replantations/revascularizations were performed, five of which failed (Table 11). Three free flaps, six pedicle flaps, three local flaps and 11 skin grafts were performed (Table 11).

\section{Machine-related injuries}

Swather injuries occurred in July, August and September (Table 2). The index finger (five of eight) was the most common digit injured (Table 3); the flexor tendon (six of 32) and skin (eight of 32) were the most commonly injured structures (Table 7). One swather injury required amputation (Table 8).
PTO injuries were more common in the colder months, with the thumb (seven of 20) being the most common digit injured (Tables 2,3). Ten of 12 PTO injuries were avulsion injuries (Table 6). Approximately half of the injuries spared the tendons (Table 7). The number of amputations equalled those injuries repaired and reconstructed (Table 8).

October was the most common month for combine injuries, with ulnar-sided digits most commonly being injured (Tables 2,3). Twenty-four of 30 injuries were laceration or crush types (Table 6). Skin, extensor tendon and bone were the most common (35 of 56) structures injured (Table 7). Four combine injuries required amputation (Table 8).

Auger injuries peaked in September but occurred throughout the year (Table 2). Thirty-two of 45 injuries included the index, long and ring fingers (Table 3). Laceration, crush and avulsion were all involved in injuring all components of the hand (Tables 6,7). Eight auger injuries required amputation (Table 8).

\section{DISCUSSION}

The referral area for the Regina Health District is southeastern Sasketchewan, which represents roughly half $(77,086$ of 154,059$)$ of the resident farm population (2).

Farming is a male-dominated occupation, with most injuries related to machine entanglement. The number of injuries per age group revealed an increasing rate with age (Figure 2). This is certainly the clinical impression. Reasons for this may include the use of outdated equipment by older farmers, and the loss of reflexes and judgement with increasing age.

Harvest is the most common farming season for injury. However, PTO injuries are more common in the colder months. This is likely related to two factors: more loose clothing is worn, which increases the risk of becoming entangled in the spinning shaft, and the oil surrounding the drive shaft is more viscous, so when the operator disengages the power to the drive shaft, it continues to spin with more torque than in warmer seasons. Farmers may be able to stop a spinning, disengaged PTO in the summer by grabbing it with their hand, but this same manoeuvre in the winter can produce a serious injury.

Eight-four per cent (94 of 112) of injuries were the result of entanglement in machinery. Ninety-two per cent (103 of 112) of injuries had some component of crush or avulsion. Eighty-four per cent (98 of 112) were open injuries. The overall amputation rate was $30 \%$. There was a $25 \%$ (five of 20) failure rate for replantations/revascularizations. This indicates a high severity of injury coupled with limited treatment options. It is a clinical impression that farmers often want to undergo the procedure that gets them back in the field the soonest, which often means amputation.

Swather injuries were usually related to changing sharp, serrated blades. This often resulted in a laceration of the flexor tendon of the index finger.

Thirty-three per cent (four of 12) of PTO injuries were associated with other injuries. The one fatality was in this group. If a farmer's coat is caught in the shaft, then thoracic and head injuries can occur. PTOs are sold with protective 
TABLE 1

Data for patients referred to Regina Health District for farm-related injuries

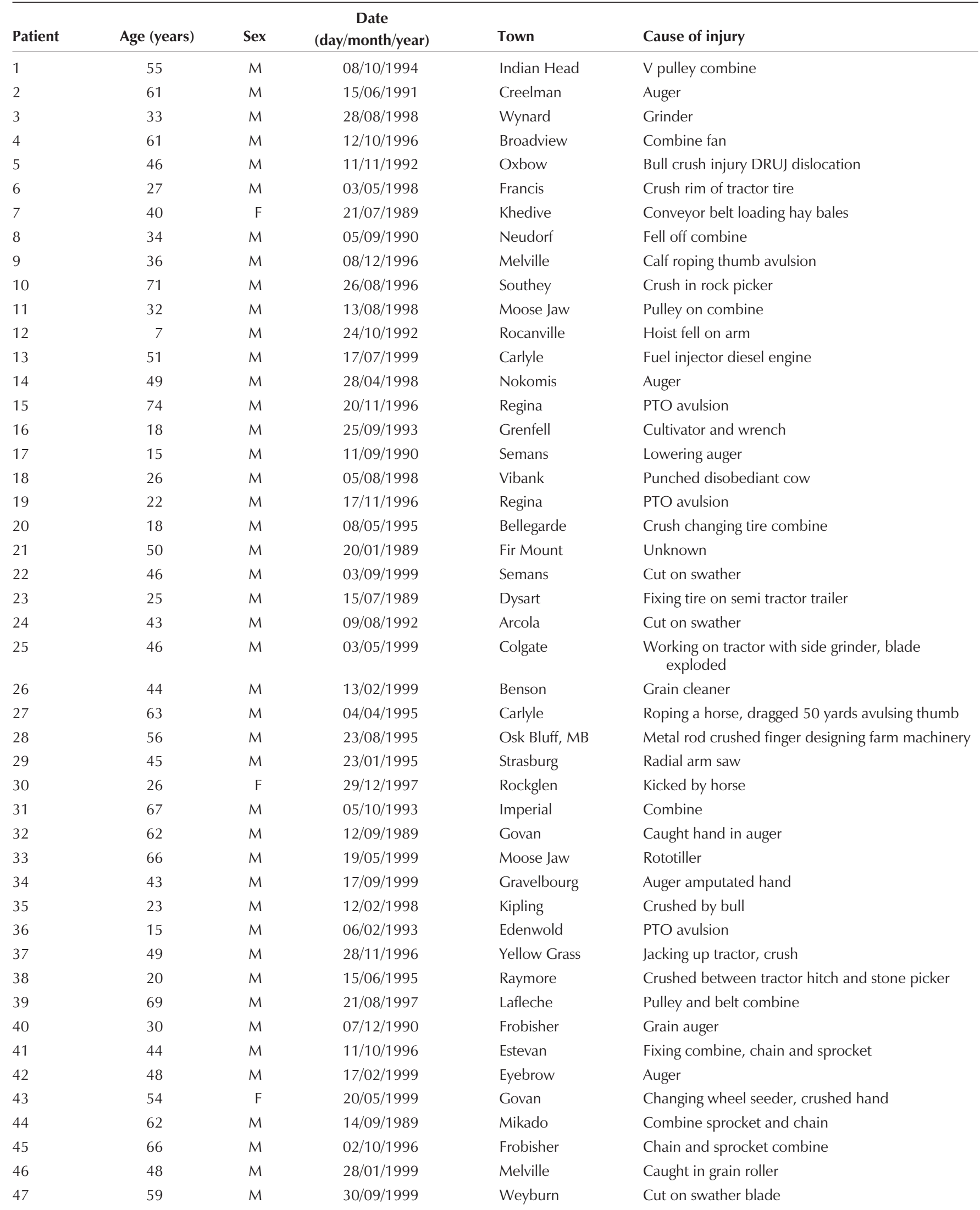


TABLE 1 (continued)

Data for patients referred to Regina Health District for farm-related injuries

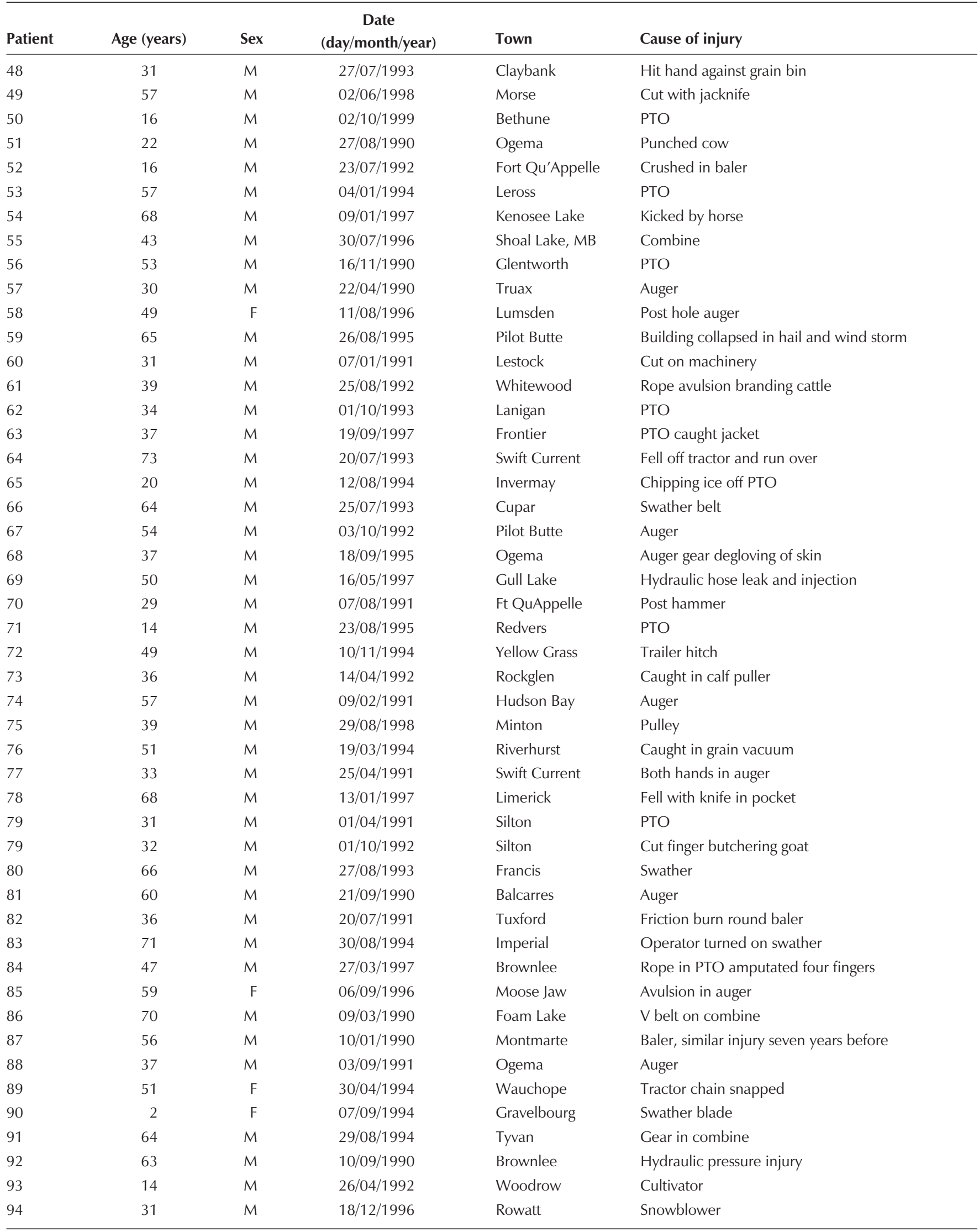


TABLE 1 (continued)

Data for patients referred to Regina Health District for farm-related injuries

\begin{tabular}{|c|c|c|c|c|c|}
\hline Patient & Age (years) & Sex & $\begin{array}{c}\text { Date } \\
\text { (day/month/year) }\end{array}$ & Town & Cause of injury \\
\hline 95 & 58 & M & 28/11/1990 & Zehner & Auger \\
\hline 97 & 19 & M & 17/09/1997 & Manor & Baler \\
\hline 98 & 40 & M & 15/07/1991 & Tyvan & Swather \\
\hline 101 & 55 & M & 10/12/1989 & Stoughton & Auger \\
\hline 102 & 39 & M & 09/12/1997 & Francis & Caught in hydraulic hopper door \\
\hline 103 & 26 & $\mathrm{~F}$ & $12 / 05 / 1989$ & Moose Jaw & Cut on headgate of horse chute \\
\hline 104 & 18 & M & 20/01/1993 & Redvers & Auger \\
\hline 105 & 56 & M & 27/12/1991 & Grenfell & Mix mill \\
\hline 109 & 59 & M & 10/11/1996 & Mclean & Cleaning combine while running \\
\hline 110 & 42 & M & 24/10/1992 & Tyvan & Belt and pulley combine \\
\hline 111 & 15 & M & 07/02/1998 & Bienfait & Kicked by cow \\
\hline
\end{tabular}

DRUJ Distal radioulnar joint; F Female; M Male; MB Manitoba; PTO Power take-off

\section{TABLE 2}

Number and most common causes of injuries occurring each month

\begin{tabular}{|c|c|c|c|c|c|}
\hline Month & $\begin{array}{c}\text { Total } \\
\text { number } \\
\text { of injuries }\end{array}$ & Swather & $\begin{array}{l}\text { Power } \\
\text { take-off }\end{array}$ & Combine & Auger \\
\hline January & 10 & & 1 & & 2 \\
\hline February & 7 & & 1 & & 2 \\
\hline March & 3 & & 1 & 1 & \\
\hline April & 6 & & 1 & & 3 \\
\hline May & 7 & & & 1 & \\
\hline June & 3 & & & & 1 \\
\hline July & 11 & 2 & & 1 & \\
\hline August & 18 & 3 & 1 & 3 & \\
\hline September & 17 & 3 & 1 & 2 & 6 \\
\hline October & 13 & & 2 & 6 & 2 \\
\hline November & 8 & & 3 & 1 & 1 \\
\hline December & 8 & & & & 2 \\
\hline
\end{tabular}

TABLE 3

Most common causes of injuries to parts of the body

\begin{tabular}{lccccc}
\hline $\begin{array}{l}\text { Body part } \\
\text { injured }\end{array}$ & $\begin{array}{c}\text { Total } \\
\text { number } \\
\text { of injuries }\end{array}$ & Swather & $\begin{array}{c}\text { Power } \\
\text { take-off }\end{array}$ & Combine & Auger \\
\hline Thumb & 27 & 1 & 7 & 3 & 3 \\
Index finger & 39 & 5 & 1 & 5 & 11 \\
Long finger & 35 & 2 & 1 & 7 & 11 \\
Ring finger & 34 & 2 & 1 & 8 & 10 \\
Small finger & 23 & 1 & 1 & 8 & 2 \\
Metacarpal & 33 & & 3 & 5 & 5 \\
Carpus & 14 & & 1 & 1 & 2 \\
Forearm & 21 & 2 & 5 & 3 & 1 \\
\hline
\end{tabular}

\section{TABLE 4}

Causes of farm-related injuries

\begin{tabular}{lc}
\hline Cause of injury & Number of injuries \\
\hline Machinery & 94 \\
Livestock & 11 \\
Other & 7 \\
\hline
\end{tabular}

TABLE 5

Number of injuries resulting from farm-related machines

\begin{tabular}{lc}
\hline Type of machine & Number of injuries \\
\hline Auger & 20 \\
Combine & 15 \\
Power take-off & 12 \\
Swather & 8 \\
\hline
\end{tabular}

TABLE 6

Type of injury resulting from machines

\begin{tabular}{lccccc}
\hline $\begin{array}{l}\text { Type of } \\
\text { injury }\end{array}$ & $\begin{array}{c}\text { Total } \\
\text { number of } \\
\text { injuries }\end{array}$ & Swather & $\begin{array}{c}\text { Power } \\
\text { take-off }\end{array}$ & Combine & Auger \\
\hline Laceration & 91 & 8 & 11 & 14 & 16 \\
Crush & 66 & 1 & 6 & 10 & 15 \\
Avulsion & 37 & & 10 & 3 & 13 \\
Burn & 9 & & 3 & 3 & \\
Injection & 4 & & & & \\
\hline
\end{tabular}


TABLE 7

Structures injured by machines

\begin{tabular}{|c|c|c|c|c|c|}
\hline Structure & $\begin{array}{c}\text { Total } \\
\text { number of } \\
\text { injuries }\end{array}$ & Swather & $\begin{array}{l}\text { Power } \\
\text { take-off }\end{array}$ & Combine & Auger \\
\hline Skin & 98 & 8 & 11 & 15 & 17 \\
\hline Extensor tendon & 52 & 3 & 6 & 8 & 13 \\
\hline Bone & 87 & 4 & 12 & 12 & 19 \\
\hline Flexor tendon & 44 & 6 & 5 & 2 & 12 \\
\hline Artery & 44 & 3 & 10 & 3 & 9 \\
\hline Nerve & 55 & 4 & 10 & 5 & 12 \\
\hline Joint & 57 & 3 & 10 & 6 & 13 \\
\hline Nail & 25 & 1 & 1 & 5 & 7 \\
\hline
\end{tabular}

TABLE 8

Treatment given for patients' farm-related injuries

\begin{tabular}{lccccc}
\hline & $\begin{array}{c}\text { Total } \\
\text { number } \\
\text { Treatment injuries }\end{array}$ & Swather & $\begin{array}{c}\text { Power } \\
\text { take-off }\end{array}$ & Combine & Auger \\
\hline Repair & 95 & 7 & 7 & 14 & 15 \\
Reconstruction & 21 & 3 & 7 & 2 & 5 \\
Amputation & 33 & 1 & 7 & 4 & 8 \\
\hline
\end{tabular}

TABLE 9

Associated injuries: nonpower take-off

Abdominal, changing tractor tire

Frostbite, caught hand in grain roller for $14 \mathrm{~h}$

Jejunal perforation, kicked by horse

Facial, rib and femur fractures, fell off and run over by tractor

\section{TABLE 10}

\section{Associated injuries: power take-off}

C5 quadriplegia, cerebellar infarct, death

Avulsion right arm at humerus, dislocation left shoulder

Fractured ribs

Friction burn to chest

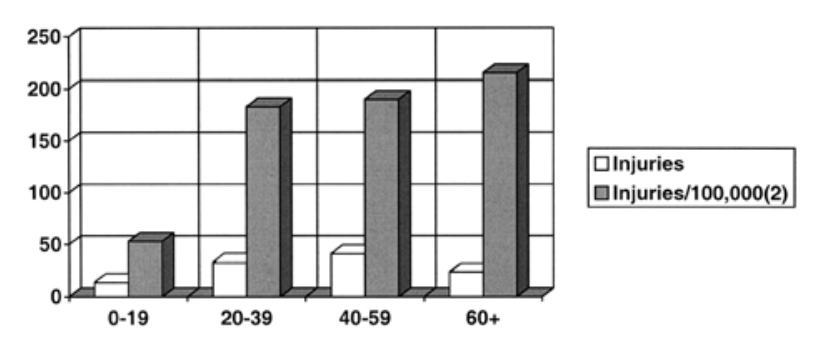

Figure 2) Farm-related injuries per 100,000 people according to age (years)
TABLE 11

Reconstructive procedures performed on patients with farm-related injuries

\begin{tabular}{|c|c|c|}
\hline Patient & Mechanism & Reconstruction \\
\hline 1 & V pulley combine & Skin graft, local flap \\
\hline 6 & Crush rim of tractor tire & Revascularization \\
\hline 9 & Calf roping thumb avulsion & $\begin{array}{l}\text { Replantation failed, } \\
\text { groin flap }\end{array}$ \\
\hline 11 & Crush in rock picker & Skin graft \\
\hline 15 & PTO avulsion & Local flap FTSG \\
\hline 19 & PTO avulsion & $\begin{array}{l}\text { Replantation failed, } \\
\text { groin flap }\end{array}$ \\
\hline 23 & Fixing tire on semi tractor trailer & Fusion PIP \\
\hline 29 & Radial arm saw & Revascularization \\
\hline 45 & Chain and sprocket combine & Skin graft \\
\hline 50 & PTO & Skin graft \\
\hline 52 & Crush in baler & Revascularization \\
\hline 56 & PTO & Replantation \\
\hline 57 & Auger & Free flap \\
\hline 58 & Post hole auger & Free flap \\
\hline 59 & $\begin{array}{l}\text { Building collapsed in hail } \\
\text { and wind storm }\end{array}$ & Revascularization \\
\hline 60 & Cut on machinery & Revascularization \\
\hline 62 & Rope avulsion branding cattle & Revascularization \\
\hline 63 & PTO & Revascularization \\
\hline 66 & Swather belt & Skin graft \\
\hline 67 & Auger & Skin graft \\
\hline 68 & Auger gear degloving of skin & Skin graft \\
\hline 69 & $\begin{array}{l}\text { Hydraulic hose leak and } \\
\text { injection }\end{array}$ & Free flap \\
\hline 70 & Post hammer & Free flap \\
\hline 71 & PTO & Free flap \\
\hline 72 & Trailer hitch & Skin graft \\
\hline 73 & Caught in calf puller & Skin graft \\
\hline 74 & Auger & Revascularization \\
\hline 75 & Pulley & Revascularization \\
\hline 76 & Caught in grain vacuum & Revascularization \\
\hline 77 & $\begin{array}{l}\text { Both hands in auger, co-worker } \\
\text { started machinery }\end{array}$ & Revascularization \\
\hline 78 & Fell with knife in pocket & Revascularization \\
\hline 80 & PTO & Revascularization \\
\hline 82 & Friction burn round baler & Groin flap, tendon graft \\
\hline 84 & $\begin{array}{l}\text { Rope in PTO amputated } \\
\text { four fingers }\end{array}$ & Replantation, skin graft \\
\hline 85 & Avulsion in auger & Replantation \\
\hline 87 & $\begin{array}{l}\text { Baler, similar injury seven } \\
\text { years before }\end{array}$ & Bone grafting \\
\hline 90 & Swather blade & Revascularization \\
\hline 94 & Snowblower & Revascularization \\
\hline 97 & Baler & $\begin{array}{l}\text { Revascularization, } \\
\text { chest flap }\end{array}$ \\
\hline 98 & Swather & Grafting and flap \\
\hline 102 & $\begin{array}{l}\text { Caught in hydraulic hopper } \\
\text { door }\end{array}$ & $\begin{array}{l}\text { Replantation failed, } \\
\text { groin flap }\end{array}$ \\
\hline 104 & Auger & $\begin{array}{l}\text { Failed replantation, } \\
\text { groin flap }\end{array}$ \\
\hline
\end{tabular}

FTSG Free transverse skin graft; PIP Proximal interphalangeal joint; PTO Power take-off 
guards that are usually removed to increase the ease of changing implements.

Combine injuries are usually related to the operator catching the ulnar side of his hand in a belt and pulley mechanism. Protective guards have often been removed to ease maintenance. The peak rate of injury in October may be related to hurried operators during a late harvest or perhaps to maintenance issues while getting the combine ready for storage for the winter.

Auger injuries occur throughout the year because farmers haul grain year round. However, there is a peak in August associated with harvest. The longest digits get caught in the turning blades. Fine mesh guards may be removed because they plug easily or do not allow the farmer to place the auger in the grain bin.

We propose a classification of hand injuries relating the pattern of injury to the specific machine that caused the injury (Figure 3 ).

The present review only looked at in-hospital admissions; however, most injuries are dealt with on an outpatient basis. Despite this limitation, patterns in the timing, scope and cause of injury were found. Farm-related injuries are serious

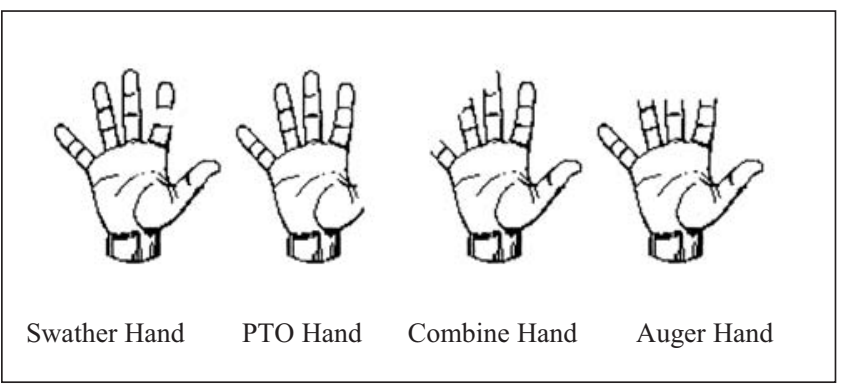

Figure 3) Hand injuries classified according to the location of the injury. PTO Power take-off

and often result in amputation. Prevention is, therefore, the key in trying to decrease disability among farmers. Further study of farmers and their work environment is warranted.

\section{REFERENCES}

1. Fatal Farm Injuries in Canada, 1990-1996. Canadian Agricultural Injury Surveillance Program. Kingston: Queen's University, 1998.

2. Resident Farm Population 1996. Agriculture Census and Population Census, Statistics Canada. Ottawa: Statistics Canada, 1996. 